\title{
COMMUNITY KNOWLEDGE OF ARJOSARI VILLAGE, KALIPARE DISTRICT, MALANG DISTRICT, EAST JAVA ABOUT SAVING OF RAINWATER
}

\author{
Rahmah Dara Lufira ${ }^{*}$, Lilik Zuhriyah², Satwika Desantina Muktiningsih33, Aldila Putri Rahayu4, \\ Ken Diah Mangar Nastiti ${ }^{5}$ \\ 1,2,3,4,5 University of Brawijaya, Malang, Indonesia \\ *rahmahdara@ub.ac.id
}

\begin{tabular}{l}
\hline Article Info \\
\hline Article history \\
Received January 21, 2021 \\
Revised February 10, 2021 \\
Accepted February 24, 2021 \\
\hline
\end{tabular}

Keywords: Concept; Knowledge, Methods; Rainwater; Saving

\begin{abstract}
Arjosari Village, Kalipare Subdistrict, Malang Regency, experiences drought every year; this makes the villagers buy water when the dry season comes. This research aims to find out how much knowledge of the people of Arjosari Village, Kalipare District, Malang Regency in saving rainwater which is used as an alternative to fulfil water needs in the dry season. The research method used was a descriptive survey method with a sample of 82 people. Survey studies are "an observer that takes samples from a single population and uses questionnaires as a primary records series tool". The results showed that the community's knowledge of the concept of saving rainwater was "high". Meanwhile, for the public's knowledge of methods of saving rainwater, there were 26 people in the "Low" category, 40 people in the "Medium" category, and 16 in the "High" category. Methods that can save rainwater are the construction of rainwater infiltration wells, bio pure infiltration holes, rainwater harvesting, and appropriate vegetation selection. This education can give the benefits that increase the public knowledge and awareness to conduct groundwater conservation to anticipate the lack of clean water in this area.
\end{abstract}

\section{INTRODUCTION}

Water as a natural resource plays an essential role in living things, including humans. Water quickly turns into an increasingly scarce resource in its development, and there is relatively no substitute source. Even though Indonesia is one of the ten water-rich countries, there are fundamental problems in its utilization. First, there are seasonal variations and spatial imbalances in water availability. During the rainy season, several parts of Indonesia experience an extraordinary abundance of water, resulting in flooding and other damage it causes.

On the other hand, in the dry season, water shortages and drought have become disasters in several other areas. The second fundamental problem is the limited amount of water that can be explored and consumed, while Indonesia's growing population causes the need for raw water to increase drastically. The problem of water quality has narrowed down the alternative water sources that the community can use. The availability and quality of clean water are currently one of the main problems faced by several local governments in 
Indonesia; the cause of this problem is a very rapid change in land use resulting in decreased infiltration and increased runoff. This condition was exacerbated by climate change which expected to change the duration and intensity of rainfall patterns. This reduced discharge can make it challenging to meet the needs of clean water or drinking water for people to consume in some of these areas. If there is no water source protection and repair effort, this decrease in discharge is believed to continue until it arrives in critical condition, where no water source can be retrieved again. In particular, in Java Island, the water-resistance risk mainly increases, except for different government, improvement, and financial activities. This situation causes water awareness needs in Java.

Drought during the dry season and flooding during the rainy season is still a problem that continues to occur. Both problems have linear-dependent behaviour, which means that drought-causing factors are also contributing factors to flooding. The contributing factors of drought and flooding are extreme climate, decreased watershed support capacity, water infrastructure planning errors, and socio-hydraulics (Maryono, 2014). Drought disasters are still common in some areas in Malang Regency. In general, this is due to a lack of drought mitigation facilities and infrastructure and a lack of understanding of drought prevention.

Arjosari Village, Kalipare District, Malang Regency is one of the villages classified as underdeveloped based on the 2016 Developing Village Index. Currently, the village has increased its status to a Developing Village in 2019. However, until now, Arjosari Village is still one of the villages with fundamental problems, namely lack of water, especially in the dry season. The drought problem in Arjosari Village, Kalipare Sub-District, Malang Regency, resulted from the lack of precise selection of vegetation planted in the area. So as a high area, Arjosari Village can only drain rainwater to lower areas without infusing water into the soil used as a water reserve. As a result, a drought occurred in Arjosari Village. In the dry season, Arjosari Village has a shortage of clean water to meet daily water needs. Therefore, people need to be encouraged to do groundwater conservation by saving rainwater needs to be improved.

Natural disasters in a region have direct implications for communities in the region. Community participation reduces and avoids the risk of essential disasters by increasing public awareness and capacity (Suryanti et al., 2010). Zein (2010) explained that the community is a party that has firsthand experience in disaster events, so that the understanding has become capital for disaster risk reduction. Adaptation results from people's attitudes that arise based on their perception and knowledge (SU Rito Hardoyo et al., 2011 ).

In keeping with Danaryanto et al. in Riastika (2011), Groundwater conservation is an attempt to guard and keep the existence, condition, and surroundings of groundwater. It maintains sustainability or continuity of availability in good enough amounts and excellent, for the continuity of its function and advantages to satisfy residing beings' wishes, each now 
and in future generations. Rainwater harvest will cut back the quantity of typhoon water, thereby alteration the impact on erosion and decreasing the weight on typhoon sewers. Reducing stormwater quantity helps hold potential stormwater pollution, akin to insecticides, fertilizers, and fossil oil products, out of rivers and groundwater (TWBD, 2005).

The benefits of water conservation explicitly outlined in the statement. The United States Environmental Protection Agency" USEPA in 1992 on the need for efficient water utilization: to meet current and future residents' needs and ensure the protection of habitats and ecosystems, then the water contained in this country must remain sustainable and renewable. Careful and efficient management of water resources is essential to achieve these intentions.

Rainwater saving is the ancient application of capturing rain runoff from roofs and different surfaces and storing it for a later purpose. Problems equivalent to urban growth, restricted water supplies, ageing stormwater infrastructure and the environmental property has prompted a revived interest within the practice (Despins, 2009). The standard of water collected in an RWH system is suffering from several factors, including 1). environmental condition resembling temperature, antecedent dry periods, and rain patterns (Evans et al.2006). 2). Natural treatment processes going down among the freshwater (Scott et al.1987; Spinks et al. 2003a), 3). Contact with construction material and therefore the dirt and trash deposited upon it between rain (Simmons et al. 2001; Van Metre \& director 2003).

This study is an early part of the Rainwater Saving Movement conducted by researchers and the people of Arjosari Village, Kalipare Sub-District, Malang Regency. This study aims to know the community's knowledge about the concept of saving rainwater and its methods.

\section{RESEARCH METHODS}

\subsection{Research Design}

This study uses a descriptive survey design. According to Singarimbun (1982: 3), survey research is "a study that takes samples from a single population and uses questionnaires as a basic data collection tool". Tika (1997: 9) argues that "surveys are a research method that aims to collect large amounts of data in the form of variables, units or individuals at the same time, data collected through certain individuals or physical samples to generalize what is studied. The variables collected can be both physical and social". Jenson and Schnack (1997) say that ancient teaching strategies tend to worsen the dangers of environmental phenomena avoided. They will discourage the learner from acting or participating in handling related issues. So the community can improve their knowledge to adapt to the impact of climate change.

In this study, the community will educate on the importance of saving rainwater as a groundwater conservation effort and providing appropriate vegetation direction for the village area. Besides, the community is also allowed to practice in the manufacture of 
rainwater wells, bio pure sinkholes, and rainwater harvesting. Time and Place of Research conducted in June-July 2020 in Arjosari village, Kalipare District, Malang Regency. The research conducted before the community received the Rainwater Saving Movement program.

\subsection{Sample and Population}

The populace is a generalization place, including gadgets or topics with specific qualities and characteristics set using researchers to be studied, after which drawn conclusions (Sugiyono, 2012). On this take a look at, the low-cost population is the whole village network of Arjosari District Kalipare Malang Regency. Meanwhile, samples are part of the number and characteristics that the population has (Sugiyono, 2012). In this study, the sample was a community figure of Arjosari Village consisting of village devices, cadet coral managers, PKK administrators, and some villagers. In this study, 82 respondents had filled out questionnaires.

\subsection{Data Collection and Analysis}

Data collection before counselling activities began by using questionnaires through Google Form, and also we used a paper to know about residences in Arjosari village. The questionnaire presented some questions about water conservation and methods or how to water conservation to know how far Arjosari village people know about water conservation. Data is descriptively analyzed through frequency distribution tables and graphs.

\section{RESULTS OF RESEARCH AND DISCUSSION}

Respondents who filled out the questionnaire were 82 people. It is demographic data from respondents who have filled out questionnaires can be seen in Table 1.

Table 1. Demographic Characteristics of Respondents

\begin{tabular}{ll}
\hline Characteristics & Total respondents \\
\hline Age & \\
-Minimum & 19 years \\
-Maximum & 68 years \\
-Mean & 40 years \\
Gender & \\
-Male & 35 Person \\
-Women & 47 Person \\
Last Education & Number (Person) \\
No school/No end & 1 Person \\
graduate elementary school & 5 Person \\
graduate junior high school & 29 Person \\
graduate senior high school & 36 Person \\
Diploma / Bachelor's degree (whether graduated or not) & 11 Person \\
\hline
\end{tabular}

IJEMI Vol.2, No.2, May 2021, pp. 164 174 


\begin{tabular}{ll}
\hline Position in Society & Number (Person) \\
PKK management & 6 Person \\
Ordinary people & 14 Person \\
Karang Taruna & 27 Person \\
Public/ religious leaders & 35 Person \\
Head of Hamlet & 0 Person \\
\hline
\end{tabular}

Knowledge of the concept of saving rainwater uses right or wrong answers about statements that have been given that lead to people's knowledge of drought. The data gave a percentage of the correct number of answers as in Table 2. this data about concept knowledge how to manage rainwater to support the community and help when the dry season is coming.

Table 2. Concept Knowledge

\begin{tabular}{|c|c|c|c|}
\hline \multirow[t]{2}{*}{ No } & \multirow[t]{2}{*}{ Question } & \multicolumn{2}{|c|}{ Correct answer } \\
\hline & & $n$ & $\%$ \\
\hline 1 & $\begin{array}{l}\text { Drought is the relationship between water supplies that are } \\
\text { far below the need for water for living, agriculture, economic } \\
\text { activities, and the environment }\end{array}$ & 82 & 100 \\
\hline 2 & $\begin{array}{l}\text { Drought or lack of water results in increased public } \\
\text { expenditure }\end{array}$ & 80 & 97.6 \\
\hline 3 & $\begin{array}{l}\text { Lack of water supply can cause direct or indirect health } \\
\text { problems }\end{array}$ & 80 & 97.6 \\
\hline 4 & $\begin{array}{l}\text { With reforestation, rainwater will be absorbed and stored by } \\
\text { tree roots and released during the dry season slowly. The } \\
\text { supply of groundwater becomes more and can help prevent } \\
\text { water shortages or drought. }\end{array}$ & 79 & 96.3 \\
\hline
\end{tabular}

Data for questions that lead to people's knowledge of rainwater saving methods gave a percentage of the correct number of answers as in Table 3.

Table 3. Knowledge of Rainwater Saving Methods

\begin{tabular}{llll}
\hline No & Question & \multicolumn{2}{l}{ Correct answer } \\
& & $\mathrm{n}$ & $\%$ \\
\hline 1 & Save rainwater & 73 & 89.0 \\
2 & The benefits of saving rainwater & 80 & 97.6 \\
3 & The way to save rainwater & 5 & 6.1 \\
4 & The advantage of saving rainwater & 59 & 72.0 \\
5 & The disadvantage of not saving rainwater & 5 & 6.1 \\
6 & Who can save rainwater? & 81 & 98.8 \\
7 & The use of infiltration wells & 68 & 82.9 \\
8 & Examples of infiltration wells & 35 & 42.7 \\
9 & Infiltration wells function during the season & 59 & 72.0 \\
10 & The advantages of infiltration wells & 80 & 97.6 \\
\hline
\end{tabular}




\begin{tabular}{|c|c|c|c|}
\hline 11 & The benefits of having infiltration wells & 76 & 92.7 \\
\hline 12 & The water that must enter the infiltration well & 8 & 9.8 \\
\hline 13 & Biopore & 77 & 93.9 \\
\hline 14 & The best place for biopore & 74 & 90.2 \\
\hline 15 & The contents for the biopore holes & 63 & 76.8 \\
\hline 16 & The depth of the biopore hole & 62 & 75.6 \\
\hline 17 & The advantages of biopore & 3 & 3.7 \\
\hline 18 & The use of organic waste in the biopore hole & 30 & 36.6 \\
\hline 19 & $\begin{array}{l}\text { The following plants that are good for soil and } \\
\text { water protection }\end{array}$ & 72 & 87.8 \\
\hline 20 & One of the benefits of the lamtoro plant & 76 & 92.7 \\
\hline 21 & Activities that can reduce groundwater & 63 & 76.8 \\
\hline 22 & Activities that can maintain groundwater & 20 & 24.4 \\
\hline 23 & Plants that are good for groundwater & 63 & 76.8 \\
\hline 24 & $\begin{array}{l}\text { The benefits of the sengon tree apart from being } \\
\text { a furniture material }\end{array}$ & 80 & 97.6 \\
\hline
\end{tabular}

The study results to 82 residents using questionnaires obtained the knowledge of the residents of Arjosari Village Kalipare sub-district about the concept and methods of saving rainwater. Moreover, the average answering accuracy was $66.67 \%$, the lowest at $37.5 \%$, the highest at $79.17 \%$. The grouping can be seen in Figure 1.

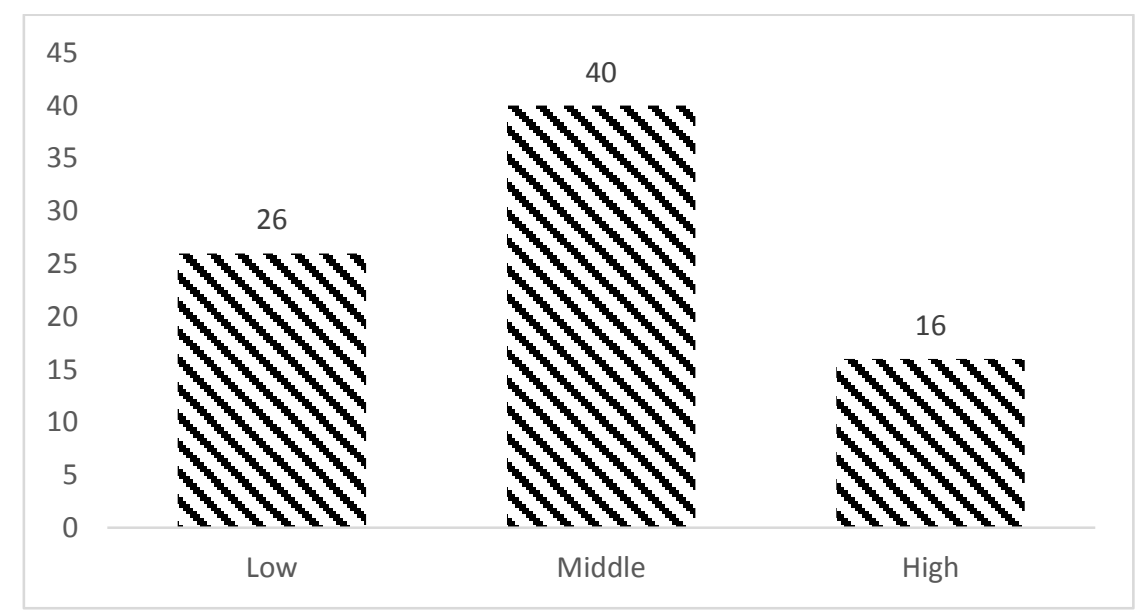

Figure 1. Recapitulation questionnaires of knowledge about concept and methods of saving rainwater

The results showed that 26 people were in the "Low" category with the accuracy of the answers ranging from $0 \%-62.50 \%, 40$ people in the "Medium" category with the accuracy of the answers ranging from $62.5 \%-70.83 \%$, and 16 people in the "High" category with The accuracy of the answers ranged from $70.83 \%-100 \%$. It shows that many Arjosari Village residents, Kalipare District, still do not know how to deal with drought. People do not know that rainwater can be used as an alternative to meet their water needs and can be obtained free and easily. Moreover, most of the total sample and population in Arjosari 
Village know the purpose of saving rainwater but do not know how to save rainwater and conserve groundwater.

In water resource conservation, there are four essential aspects: existence, sustainability, capacity, and water resources function. For all these aspects to be fulfilled, it requires building construction as a water resource conservation solution.

Sunjoto in Anwar (2005) argues that the effort to build rainwater well is a water conservation technique that is a human effort in maintaining, improving, and developing water use by its provisions and can be achieved by enlarging groundwater landfills, reducing the dimensions of drainage networks, maintaining groundwater elevation, preventing seawater intrusion for coastal areas, and reducing the level of soil water pollution.

Groundwater may be a renewable natural resource, however uncontrolled exploitation with a scarcity of awareness to preserve; will cause the water crisis because of the decreasing standard of life. Therefore, it is necessary to undertake a program of conservation of groundwater and building awareness of society. There are some ways groundwater conservation; one straightforward program that will harvest home rain through recharge wells.

Rainwater harvesting described as a technique for inducing, amassing, storing and keeping local floor runoff for agriculture in arid and semi-arid areas (Boers \& Ben-Asher 1982).

Biopori Sinkhole, according to Regulation of the Minister of Forestry Number: P.70/Menhut-II/2008 about The Technical Guidelines for Forest and Land Rehabilitation, is a hole in the soil formed due to various activities of organisms in it, such as worms, rooting plants, termites, and other soil fauna. The holes formed will fill the air and be where the water passes in the ground.

Water infiltration in the soil happens vertically and horizontally. The vertical water infiltration price is smaller than the horizontal water infiltration price. For satisfactory-grained soils, the rate of water impregnation is horizontally ten times larger than the price of vertical infiltration. From that is the significance of creating the rainfall hollow (LR) into the soil. Garage of water within the soil and the fee of infiltration of water into the soil will boom further after the formation of biopore. Biopore shaped due to small animals' activity inside the soil and the roots of trees weathered, as can be seen in Figure 2. 


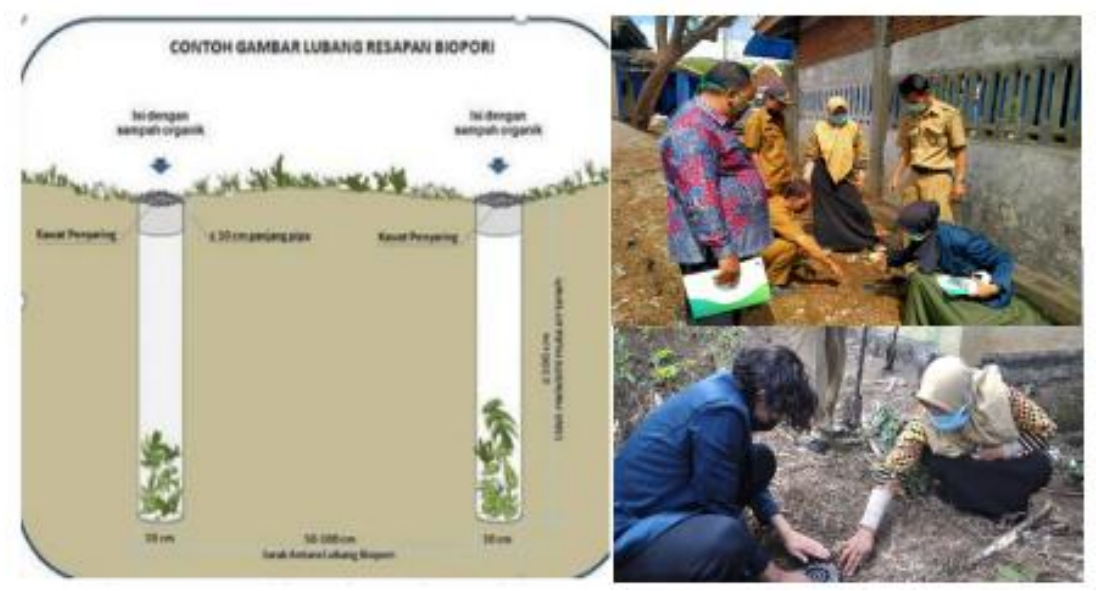

Figure 2. Biopori sinkhole in Arjosari Village

One method of water conservation is harvesting rainwater or "Rain Water Harvesting". It was collecting, accommodating and storing rainwater. Rainwater harvesting is defined as collecting or sheltering rainwater or surface flow at times of high rainfall for subsequent use at low rainwater times. How it works: water from the roof gutter enters the pipe that previously had a filter. Then it is accommodated in a reservoir that previously contained a fine particle filter. The collected water in the reservoir goes to the filter pipe and then comes out as clean water. If the water in the reservoir is excessive and abundant, it will enter the absorption well, as explained in Figure 3.

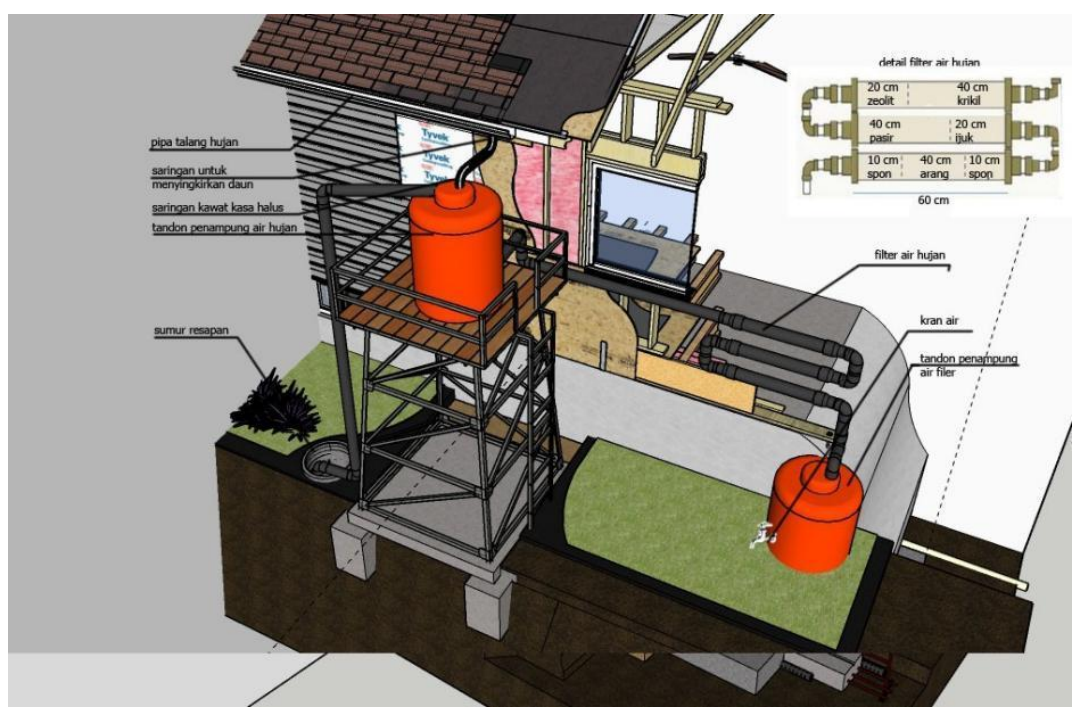

Figure 3. Water-Saving Method water reservoir, filtration and absorption well

Rainwater harvesting systems have not been used as a primary tool in supplying a safe source of drinking water. The critical barriers for the rainwater harvesting system can be analyzed from three perspectives: technical, economic, and social.

Besides that, vegetation is also a key element in soil and water conservation efforts. The existence of forests will make the soil surface covered with litter and humus. Soil becomes 
porous so that water is easily absorbed into the soil and replenishes groundwater supplies. It will help increase groundwater supplies (figure 4).
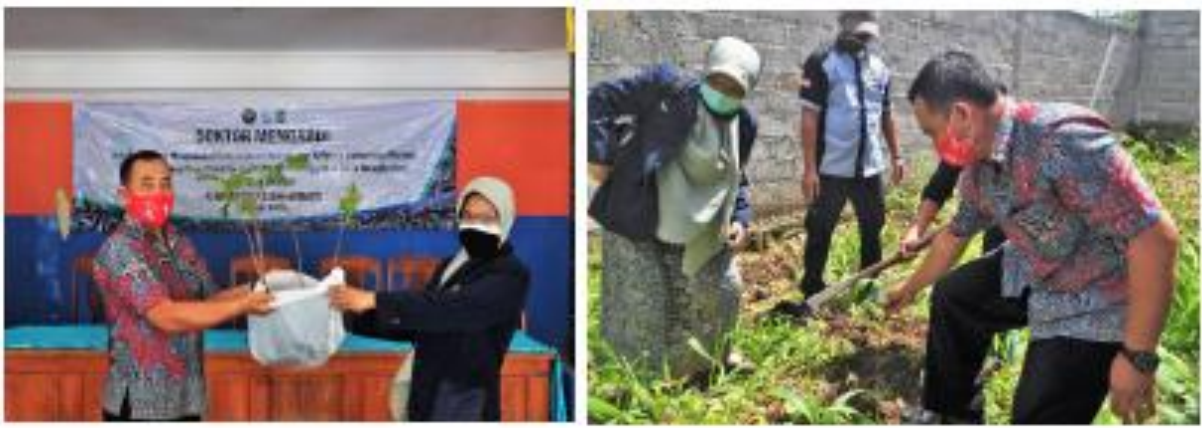

Figure 4. Kluwih tree as a part Vegetation plan in Arjosari Village

The purpose of groundwater conservation efforts is to meet the increasingly limited water needs. Moreover, it can indirectly reduce the risk of drought and flooding. This conservation effort requires all parties' commitment to helping water sustainability and environmental sustainability as life support for the future.

In response to the lack of knowledge of the residents of Arjosari Village Kalipare Subdistrict in anticipation of the drought in the area, the research team initiated a rainwater saving program for Arjosari Village kalipare sub-district and expected to help overcome the drought problem that has been occurring in Arjosari Village. Besides, providing counselling on saving rainwater can help reduce the costs that previously had to be incurred to buy water to meet its needs. Arjosari Villagers are very enthusiastic about this program. Also, this program has benefits that can increase public knowledge and awareness to conduct groundwater conversion to anticipate the lack of clean water.

Through questionnaires, residents also stated that residents use water from springs, HIPAM, Dams, Drill wells, digging wells, private wells, and pump wells to meet daily water needs. Some residents use a combination of water sources and dams. In the dry season, the cost incurred by residents each month ranges from Rp. 12,000., - Rp. 750.000., with an average expenditure of Rp. 63,000.

\section{CONCLUSION}

From this research, it can be said that resident knowledge about the concept of saving rainwater is "high". As for the public's knowledge of rainwater saving methods, there are 26 people in the category "Low", 40 people in the category of "Medium", and 16 in the category "High". The least known thing about the resident is about the well.

Therefore, efforts needed to improve resident knowledge about water resource conservation, especially in saving rainwater. This research can create drought-resilient communities by providing education and also exemplifying a rainwater harvesting system. 
Raising public focus in hainwater hesting can carried out in several approaches which include: extra pilot tasks will be carried out at nearby ranges; promoting and education of rainwater maintenance, and harvesting can carry out at all levels of the education system, and an innovative micro-investment system might make in cooperation with activities of the public sector.

\section{REFERENCES}

Boers, T. M. and J. Ben-Asher (1982) "A review of rainwater harvesting". In Agriculture Water Management. 5:145-158.

Christopher, D; Khosrow Farahbakhsh and Chantelle Leidl.; 2009; Assessment of rainwater quality from rainwater harvesting systems in Ontario, Canada. Journal of Water Supply: Research and Technology-AQUA, 58.2

Daniel, J., Neolaka, A., \& Nasution, N. (2012). Community Awareness in Making Rainwater Infiltration Wells (Study at RW. 02 Kelurahan Kebon Jeruk, West Jakarta). Jurnal Menara, $7(1), 14-14$.

Evans, C. A., Coombes, P. J. \& Dunstan, R. H. (2006) Wind, rain and bacteria: the effect of weather on the microbial composition of roof-harvested rainwater. Water Res. 40(1), 37-44

Fo"rster, J. (1998). The influence of location and season on the concentrations of macroions and organic trace pollutants in roof runoff. Water Sci. Technol. 38(10), 83-90.

Harsoyo, B. (2010). Rain water harvesting technique as an alternative to save water resources in DKI Jakarta. Jurnal Sains \& Teknologi Modifikasi Cuaca, 11 (2), 29-39.

Iriani, K., Gunawan, A., \& Besperi, B. (2013). Planning of rainwater infiltration wells for groundwater conservation in residential areas (case studies in Housing RT. II, III, and IV Perumnas Lingkar Timur Bengkulu). Inersia, Jurnal Teknik Sipil, 5(1), 9-22.

Jensen BB, Schnack K. (1997). The Action Competence Approach in Environmental Education. Environ. Educ. Res. 1997:3:163-178.

Kim, Y., Han, M., Kabubi, J., Sohn, H. G., \& Nguyen, D. C. (2016). Community-based rainwater harvesting (CB-RWH) to supply drinking water in developing countries: lessons learned from case studies in Africa and Asia. Water Science and Technology: Water Supply, 16(4), $1110-1121$.

Maryono, A. (2020). Rain Harvesting. UGM PRESS.

Maryono, A. (2020). floods, droughts and environment. UGM PRESS.

Muryani, Chatarina., Sarwono., dan Dwi Hastuti. (2016). Community Adaptation to Drought Disaster in Grobogan Regency, Central Java. 1-8.

Prihanto, Y., Koestoer, R. H., Sutjiningsih, D., \& Darmajanti, L. (2018, November). Rain harvesting patterns for a dynamic secondary city: a case study of Semarang City. 
In IOP Conference Series: Earth and Environmental Science (Vol. 202, No. 1, p. 012065). IOP Publishing.

Prinz, D., \& Singh, A. (2000). Technological potential for improvements of water harvesting. Gutachten für die World Commission on Dams, technical papers, 126.

Ruqoyyah, R., Wiyarti, F., \& Novitasari, R. (2018, July). Rain Water Harvesting As an Effort to Fulfill Clean Water in the Jakarta Special Region. In Seminar Nasional Hari Air Sedunia (Vol. 1, No. 1, pp. 26-32).

Samekto, C., \& Winata, E. S. (2010, June). Potential of water resources in Indonesia. In the National Seminar: Application of Clean Water Supply Technology for Regencies / Cities in Indonesia (pp. 1-20).

Sarminingsih, A. (2008). Kajian Upaya Konservasi Sumber Daya Air Dalam Peningkatan Kesadaran Masyarakat. Jurnal Presipitasi: Media Komunikasi dan Pengembangan Teknik Lingkungan, 5(2), 42-48.

Scott, R. \& Waller, D. (1987). Water quality analysis of a rainwater cistern system in Nova Scotia, Canada. In: Proceedings of the 3rd International Rainwater Collection System Association Conference. Khon Kaen, Thailand, January 1987.

Simmons, G., Hope, V., Lewis, G., Whitmore, J. \& Gao, W. (2001). Contamination of potable roof-collected rainwater in Auckland. NZ Water Res. 35(6), 1518-1524.

Spinks, A. T., Coombes, P., Dunstan, R. H. \& Kuczera, G. (2003a). Water quality treatment processes in domestic rainwater harvesting systems. In: Proceedings of the 28th International Hydrology and Water Resources Symposium, Wollongong, Australia, 10-14 November 2003.

Sudiajeng, L., Wiraga, I. W., Parwita, I. G. L., \& Santosa, G. (2017). Domestic recharge wells for rainwater-harvesting in Denpasar City, Bali-Indonesia. International Journal of GEOMATE, 13(36), 50-57.

Syahruddin, M. H., \& Halide, H. (2019, August). Groundwater Conservation with Hole Infiltration of Biopore Cube. In IOP Conference Series: Earth and Environmental Science (Vol. 279, No. 1, p. 012021 ). IOP Publishing.

Taylor, R., Sloan, D., Cooper, T., Morton, B. \& Hunter, I. (2000). A waterborne outbreak of Salmonella Saintpaul. Commun. Dis. Intell. 24(1 1), 336-340.

TWDB (Texas Water Development Board) (2005). The Texas Guide to Rainwater Harvesting, 3rd edition. Texas Water Development Board, Austin, Texas.

Van Metre, P. C. \& Mahler, B. J. (2003). The contribution of particles washed from rooftops to contaminant loading to urban streams. Chemosphere 52(10), 1727-1741 